\title{
Research on the Influence of Leadership Style on Employee Innovation Behavior in Agricultural Science and Technology enterprises
}

\author{
$\mathrm{Na} \mathrm{Fu}{ }^{* 1, a}$, Tongyue Zhang ${ }^{1}$, Xiaodan $\mathrm{Nie}^{1}, \mathrm{Min}^{\mathrm{L}}{ }^{1}$, \\ ${ }^{1}$ Tianjin Agricultural University, Tianjin, China
}

\begin{abstract}
Innovation is the key factor to promote agricultural modernization. Employees are the implementers of innovation, and the managers, as the leaders of enterprises, have an important impact on employees' innovation behavior. This paper takes agricultural science and technology enterprises as the research object, studies the influence of different leadership styles on employees' innovation behavior, and proposes suggestions to improve the leadership style to promote employees' innovation behavior, so as to improve the innovation ability of agricultural science and technology enterprises.
\end{abstract}

\section{Introduction}

Innovation is the primary driving force for development and the most effective way to gain market competitiveness and sustainable development [1]. Scientific and technological progress and innovation is the key factor for accelerating agricultural modernization. In 2017, the contribution rate of China's agricultural science and technology progress reached $57.5 \%$. It was still lower than the average level of $70 \%$ of developed countries. And there is still a big gap between China and the world's agricultural power ${ }^{[2]}$.

How to promote agricultural sci-tech organizations to achieve efficient innovation? This is closely related to the innovation behavior of employees in the organization. Employees' innovation behavior is not only an important part of individual performance, but also the foundation of organizational innovation. and organizational innovation is exactly the extension of individual innovation ${ }^{[3]}$.

However, as one of the organizational situational factors, leadership style plays the role of model and atmosphere builder for employees' innovative behavior.

Different leadership styles deliver different job opportunities, market prospects and unconventional thinking to employees, and different leaderships have different influences on employees' innovative behavior ${ }^{[4]}$. Therefore, it is of great practical significance to study the relationship between leadership style and employee innovation behavior in agricultural organizations.

\section{Literature Review}

The theory of leadership style was first proposed by Lewin, a famous psychologist and researcher of the University of Iowa. According to different criteria, leadership styles can be divided into different types. At present, the more popular division is to divide the leadership style into transactional and transformational (burns, 1978) [5]. Therefore, this literature review is mainly around influence of the two leadership styles on employee innovation.

\subsection{Transactional leadership}

Transactional leadership first appeared in Burns' Book "Leaders" in 1978, also known as contractual leadership, which refers to the way the leader managing employee by barter approach. Burns believes that transactional leadership is a kind of leadership behavior with strong purpose. In order to better achieve organizational goals, leaders will specify rewards for subordinates' work and punish those who do not conform to standards. In his opinion, transactional leadership is a process in which leaders and subordinates determine a mutually beneficial goal through negotiation without damaging their interests, with the purpose of maximizing organizational interests and minimizing losses. Bass (1985) points out that transactional leader focuses on the two-way relationship between organizational leaders and the followers ${ }^{[6]}$. Bass believes that transactional leadership is based on the principle of contractual trading. It will strengthen communication and exchange with employees on the basis of reward mechanism. Leaders have a clear division of labor between subordinates, and they need to be satisfied in their work, so as to increase employees' trust in the leadership. On this basis, Bass and Avolio (1990) divided transactional leaders into Contingent rewards and Management by Exception ${ }^{[7]}$. Bass (1999) pointed out that contingency rewards pay more attention to role requirements and rewards, while exception management is a negative transaction, including positive criticism, 
negative feedback and negative reinforcement ${ }^{[8]}$.

There is no consensus on the relationship between transactional leadership and employee innovation behavior. For example, Amabile (2004) shows that transactional leadership style can significantly predict employees' innovative behavior ${ }^{[9]}$. However, Lee (2008) found that transactional leadership has a negative impact on the innovation of employees ${ }^{[10]}$.

\subsection{Transformational Leadership}

The transformational Leadership first appeared in Downton's "Rebel Leadership" in the early 1970s. In 1978, Burns, the pioneer of American leadership research, conceptualized it in his classic work "Leaders", believing that transformational leaders are organizational leaders with high moral quality and ability, they can effectively use the motivation of followers to achieve better goals. As a master who developed the theory of transformational leadership, Bass (1985) believed that transformational leader can influence the values and spiritual pursuits of followers, and can inspire them to put organizational interests ahead of their own. Antonakis (2012) pointed out that transformational leaders influence their followers through the power of role models, and make themselves become role models by regulating their behaviors, so that followers have a sense of identity with them and keep pace with them ${ }^{[11]}$.

There is also no consensus on the impact of transformational leadership on employee. Most studies show that transformational leadership is positively correlated with employees' innovation behavior. For example, Jung et al. (2013) found that transformational leaders can improve employee's self-efficacy, and thus show more innovative behaviors by deliver a good vision to employees, give them personalized care, help them build confidence ${ }^{[12]}$. Shin and Zhou (2003) pointed out that transformational leadership can promote the generation of employees' innovative behaviors from the four dimensions: personality care, charisma, leadership charm and intellectual stimulation ${ }^{[13]}$. However, a few researchers have different views. For example, Basu (2010) pointed out that transformational leadership is negatively correlated with employees' innovation behaviors [14]. Jaussi (2003) believed that there was no significant relationship between the two ${ }^{[15]}$.

To sum up, whether it is transformational leadership or transactional leadership, the impact on employees' innovation behavior is positive or negative, the current researches haven't a conclusion. Moreover, the above researches are distributed in various industries without considering the influence of organizational characteristics. Therefore, it is of great theoretical significance to define organizational types in agricultural science and technology enterprises and to study the influence of leadership style on employees' innovation behavior in such organizations.

\section{Research hypothesis and analysis}

\subsection{Research hypothesis}

Although the existing literature has not reached a consistent conclusion on whether the leadership style of enterprises has a positive impact on the innovation ability of employees, considering the particularity of agricultural science and technology enterprises, leaders' care and trust are one of the key factors affecting the technological innovation ability of agricultural science and technology enterprises. This paper makes the following assumptions about the relationship between leadership style and employee innovation behavior in agricultural science and technology enterprises.

Hypothesis 1: There is a positive correlation between contingent reward transactional leadership style and employee innovation behavior.

Hypothesis 2: There is a negative correlation between exception management transactional leadership style and employee innovation behavior.

Hypothesis 3: There is a positive correlation between transformational leadership style and employee innovation behavior.

\subsection{Research Tools}

\subsubsection{Measurement of leadership style}

One of the most representative scales to measure transactional leadership is the multi factor Leadership Style Questionnaire (MLQ) developed by Bass and Avoli (1990). This scale can effectively measure transactional leadership behaviors. After many empirical studies at home and abroad, its reliability and validity have been confirmed.

Table1. Transactional Leadership Style Measurement Scale

\begin{tabular}{ccc}
\hline $\begin{array}{c}\text { Measure } \\
\text { dimension }\end{array}$ & number & content \\
\hline $\begin{array}{c}\text { Contingency } \\
\text { Reward }\end{array}$ & A1 & $\begin{array}{c}\text { Rewards for completing task } \\
\text { Acknowledge employees' } \\
\text { achievements }\end{array}$ \\
& A4 & $\begin{array}{c}\text { Rewards is consistent with } \\
\text { employees' efforts } \\
\text { Express satisfaction when } \\
\text { employees completing tasks on } \\
\text { time }\end{array}$ \\
\hline $\begin{array}{c}\text { Exception } \\
\text { management }\end{array}$ & A6 & $\begin{array}{c}\text { pays attention to employees' } \\
\text { mistakes } \\
\text { pays attention to behaviors non- } \\
\text { compliance with regulations } \\
\text { knows employees' mistakes }\end{array}$ \\
& A8 & $\begin{array}{c}\text { do not intervene when there is no } \\
\text { problem }\end{array}$ \\
\hline
\end{tabular}

On this basis, combines with the national conditions of China and the characteristics of agricultural science and technology enterprises, the article develops Table 1 to measure the transactional leadership style. The scale uses 5-point scoring (from $5=$ completely consistent to $1=$ completely inconsistent) to measure.

For transformational leadership measurement scale, 
this article also references the MLQ of Bass, combining with China's national conditions and the characteristics of agricultural science and technology enterprises, develop the table 2. And also use 5 score measurement.

Table2. transformational leadership measurement scale

\begin{tabular}{|c|c|c|}
\hline $\begin{array}{c}\text { Measure } \\
\text { dimension }\end{array}$ & number & content \\
\hline \multirow{4}{*}{$\begin{array}{l}\text { Leader } \\
\text { charm }\end{array}$} & A9 & $\begin{array}{l}\text { infects employees with its own } \\
\text { charm }\end{array}$ \\
\hline & A10 & $\begin{array}{c}\text { don't take employees' } \\
\text { achievements as their own }\end{array}$ \\
\hline & A11 & $\begin{array}{l}\text { sacrifice personal interests for } \\
\text { the collective good }\end{array}$ \\
\hline & A12 & $\begin{array}{c}\text { demonstrates important values } \\
\text { and beliefs to employees }\end{array}$ \\
\hline \multirow{4}{*}{$\begin{array}{l}\text { Vision } \\
\text { incentive }\end{array}$} & A13 & fully motivate employees \\
\hline & A14 & $\begin{array}{l}\text { Communicates the } \\
\text { organization's expectations } \\
\text { with employees }\end{array}$ \\
\hline & A15 & $\begin{array}{l}\text { enables employees to complete } \\
\text { tasks efficiently }\end{array}$ \\
\hline & A16 & $\begin{array}{c}\text { depicting a desirable future for } \\
\text { employees }\end{array}$ \\
\hline
\end{tabular}

\begin{tabular}{|c|c|c|}
\hline \multirow{4}{*}{$\begin{array}{l}\text { Intellectual } \\
\text { stimulation }\end{array}$} & A17 & $\begin{array}{l}\text { encourages employees to break } \\
\text { mental barriers }\end{array}$ \\
\hline & A18 & $\begin{array}{l}\text { Encourages employees to solve } \\
\text { problems in new ways }\end{array}$ \\
\hline & A19 & $\begin{array}{l}\text { create conditions for } \\
\text { employees to play their } \\
\text { strengths }\end{array}$ \\
\hline & $\mathrm{A} 20$ & $\begin{array}{l}\text { Encourages employees to } \\
\text { develop new methods }\end{array}$ \\
\hline \multirow{4}{*}{$\begin{array}{l}\text { Personality } \\
\text { care }\end{array}$} & $\mathrm{A} 21$ & $\begin{array}{l}\text { regards employees as their } \\
\text { own children }\end{array}$ \\
\hline & $\mathrm{A} 22$ & Focus on employees' lives \\
\hline & A23 & Help employees \\
\hline & A24 & $\begin{array}{c}\text { Advice to staff on problem } \\
\text { solving }\end{array}$ \\
\hline
\end{tabular}

- Measurement of employee innovation behavior

Based on the scale developed by Scott and Bruce (1994) [16], considering the national conditions of China and the characteristics of agricultural science and technology enterprises, this paper designs scale 3 for the measurement of employees' innovation behavior, and also uses 5-point scoring (from $5=$ fully consistent to $1=$ completely inconsistent) to measure.

Table3. Employee behavior scale

\begin{tabular}{ccc}
\hline Measure dimension & number & content \\
\hline B1 & B2 & Break the ideological shackles and put forward new ideas that are conducive to innovation \\
Employee behavior & B3 & Actively communicate your new ideas to others and strive for their approval \\
& B5 & Make full use of the resources to make innovative ideas come true \\
& B6 & Constantly put forward constructive suggestions for the rapid development of enterprises \\
\end{tabular}

\section{- Data sources and collation}

In this paper, 630 employees from 126 agricultural science and technology enterprises in Beijing, Tianjin, Hebei, Jiangsu and Zhejiang were selected for investigation. 52 invalid questionnaires were eliminated, and the remaining 578 were valid questionnaires, with an effective rate of $91.75 \%$. The sample characteristics of the questionnaire are shown in Table 4. At the same time, SPSS 24.0 is used for data processing.

Table4. Descriptive statistics of samples

\begin{tabular}{|c|c|c|c|c|}
\hline Index & Category & Frequency & Proportion (\%) & Cumulative proportion \\
\hline \multirow{2}{*}{ Sex } & Male & 396 & $68.51 \%$ & $68.51 \%$ \\
\hline & Female & 182 & $31.49 \%$ & $100.00 \%$ \\
\hline \multirow{4}{*}{ Age } & Under 30 & 165 & $28.55 \%$ & $28.55 \%$ \\
\hline & $31-40$ & 323 & $55.88 \%$ & $84.83 \%$ \\
\hline & $40-50$ & 70 & $12.11 \%$ & 96.54 \\
\hline & Over 50 & 20 & $3.46 \%$ & $100.00 \%$ \\
\hline \multirow{4}{*}{ education } & Junior college and below & 28 & $4.84 \%$ & $4.84 \% \%$ \\
\hline & undergraduate & 208 & $35.99 \%$ & $39.45 \%$ \\
\hline & master & 220 & $38.06 \%$ & $77.51 \%$ \\
\hline & doctor & 150 & $22.49 \%$ & $100.00 \%$ \\
\hline \multirow{2}{*}{ Working years } & 1 year or less & 36 & $6.23 \%$ & $6.23 \%$ \\
\hline & 1-3 years & 156 & $26.99 \%$ & $33.22 \%$ \\
\hline
\end{tabular}




\begin{tabular}{ccccc} 
& $3-5$ years & 216 & $37.37 \%$ & $70.59 \%$ \\
$5-10$ years & 152 & $26.30 \%$ & $96.89 \%$ \\
& Over 10 years & 18 & $3.11 \%$ & $100.00 \%$ \\
\hline \multirow{3}{*}{ Job title } & junior & 57 & $9.86 \%$ & $9.86 \%$ \\
& intermediate & 356 & $61.59 \%$ & $71.45 \%$ \\
& senior & 165 & $28.55 \%$ & $100.00 \%$ \\
\hline
\end{tabular}

\section{Empirical results and analysis}

\subsection{Reliability and validity analysis}

Cronbach's A coefficient was adopted to verify the reliability of the scale in this paper. The Cronbach's a value of all variables was above 0.7 , which indicate that the scale had high reliability and met the research requirements. KMO value was used to test the validity of the variable. The KMO value was 0.875 , greater than 0.5 , indicating that the validity met the research standard to ensure that subsequent factor analysis could be carried out.

\subsection{Descriptive statistics of variables}

The descriptive statistics and sample variance analysis results of the scale are shown in Table 5. From the statistical results, it can be seen that the average value of transactional leadership contingency rewards is 3.862 , higher than the average value of exceptional management, indicating that leaders should use more relevant incentive mechanisms in the management process. For transformational leadership, the overall test of the difference in the average number of the four dimensions reached a significant level, and the post-test showed that the average score of leadership charm was significantly higher than that of the other three dimensions, and the average score of personality care was significantly lower than that of the other three dimensions. It can be concluded that employees' perceived leadership care for their own personality is the least, while the influence of leadership charm is the strongest. At the same time, the standard deviation of all variables is less than 1 , indicating a high level of sample data set.

Table5. Descriptive statistics of variables

\begin{tabular}{ccc}
\hline Variables and Dimensions & Average & $\begin{array}{c}\text { Standard } \\
\text { deviation }\end{array}$ \\
\hline Transactional leader & 3.682 & 0.526 \\
Contingency reward & 3.865 & 0.669 \\
Exception management & 3.056 & 0.565 \\
\hline $\begin{array}{c}\text { Transformational } \\
\text { leadership }\end{array}$ & 4.169 & 0.667 \\
Leader Charm & 4.255 & 0.588 \\
Vision incentive & 4.158 & 0.698 \\
Intellectual stimulation & 4.147 & 0.649 \\
Personality care & 4.120 & 0.762 \\
\hline
\end{tabular}

\subsection{Correlation analysis between variables}

This study uses Pearson correlation analysis method to analyze the significance of the correlation between contingent reward transactional leadership style, exception management transactional leadership style, transformational leadership style and employee innovation behavior. See Table 6 for details.

Table6. Correlation coefficient between variables $(n=578)$

\begin{tabular}{|c|c|c|c|c|c|c|c|c|c|}
\hline & 1 & 2 & 3 & 4 & 5 & 6 & 7 & 8 & 9 \\
\hline $1 \mathrm{Sex}$ & 1 & -- & -- & -- & -- & -- & -- & -- & -- \\
\hline 2 Age & $-0.155^{*}$ & 1 & -- & -- & -- & -- & -- & -- & -- \\
\hline 3 Education & $0.126^{*}$ & $-0.270^{*}$ & 1 & -- & -- & -- & -- & -- & -- \\
\hline 4 Working years & $-0.182^{*}$ & $0.430^{* *}$ & $0.423^{* *}$ & 1 & -- & -- & -- & -- & -- \\
\hline 5 Title & $0.105^{*}$ & $0.402^{* *}$ & $0.336^{* *}$ & $0.543^{* *}$ & 1 & -- & -- & -- & -- \\
\hline 6 Contingency reward & $-0.068^{*}$ & $-0.053^{*}$ & $0.202^{* *}$ & $-0.063^{*}$ & $-0.001^{*}$ & 1 & -- & -- & -- \\
\hline 7 Exception management & $-0.059^{*}$ & $-0.113^{*}$ & $-0.045^{*}$ & $-0.191^{* *}$ & $-0.023^{*}$ & $-0.184^{*}$ & 1 & -- & -- \\
\hline 8 Transformational & $-0.153^{*}$ & $-0.092^{*}$ & $-0.015^{*}$ & $-0.175^{* *}$ & $-0.066^{*}$ & $0.613^{* *}$ & $-0.132^{*}$ & 1 & -- \\
\hline 9 Employee innovation & $-0.178^{*}$ & $0.033^{* *}$ & $-0.056^{*}$ & $-0.097^{*}$ & $0.013^{*}$ & $0.452^{* *}$ & $-0.176^{* *}$ & $0.676^{* *}$ & $0.664^{* *}$ \\
\hline
\end{tabular}

Note: * the correlation is significant at the level of $0.05 ; *$ the correlation is significant at the level of 0.01

By analyzing the data in Table 6 , it is found that the correlation coefficients between contingent reward transactional leadership style, exception management transactional leadership style, and transformational leadership style and employee innovation are 0.452, 0.176 , and 0.676 respectively, and all of them are at the 
level of 0.01, indicating significant influence effect. Hypothesis 1, 2, and 3 are all valid. At the same time, it can also be found from the above data that, except for exceptional management leadership style, the remaining two leadership styles can promote the enthusiasm of employees' behaviors. However, the Pearson coefficient of the two styles is not the same, so the degree of influence is also different. The larger the coefficient is, the greater the influence degree is, and vice versa.

\subsection{Analysis of empirical results}

\section{- Influence of the two dimensions of transactional leadership is relative}

Through the empirical research, it is found that the contingent reward transaction leader has a positive effect on employees' innovation behavior, while exception management transaction leader has a negative impact. In other words, two dimensions of transactional leadership, contingency reward and exception management, have opposite effects on employees' innovation behaviors.

\section{- Transformational leadership has a positive impact on employees' innovative behavior}

Transformational leaders not only pursue change, but also become role models for employees by constantly improving themselves and improving their personality charm, thus having a positive impact on employees' innovation behaviors.

\section{- Transformational leadership has a greater impact on employees' innovative behavior}

The theory of transformational leadership is based on the theory of transactional leadership. Compared with transactional leadership, transformational leadership can enable employees to have more mature ideas and improve their business ability. Therefore, transformational leadership has a greater impact on employee behavior than transactional leadership.

\section{Suggestions on improve the innovation behavior of employees}

\subsection{Enterprises should establish innovation consciousness}

Innovation consciousness can help enterprises find a safe and stable road in the surging market competition. Innovative management mode and creative thinking can stabilize the status of enterprises in the reform, which is also applicable to agricultural science and technology enterprises. Therefore, agricultural science and technology enterprises should constantly establish the consciousness of innovation and inject the concept of continuous innovation into enterprise culture, including stable cultural concept and historical tradition, as well as unique management concept. Only by maintaining innovative ideas in the company and constantly injecting new blood into the enterprise, the enterprise will not be stagnant and fall behind other similar enterprises. Managers with innovative ideas should play a leading role, encourage their employees to use their imagination, keep alert at all times, and regard the development of the enterprise as their own development, and take the company as their own family, so as to exert their potential for the happiness and stability of the family.

\subsection{Flexible transition between transactional and transformational leadership}

Each leadership style is not the only one that can bring benefits to the organization. A leader can also possess multiple leadership styles at the same time. There are significant differences between each style, but they will not contradict each other. When the environment changes, a leadership style no longer adapts to the change of organizational environment, it is necessary to reform and change a style that matches the current environment. When the transactional leadership style on employees is not significant or may have a negative impact, transformational leadership style can pick up the slack, change the saturation state, and vice versa. If an enterprise wants to have no worries in the reform and development, it should flexibly use a variety of leadership styles to seek advantages and avoid disadvantages.

\subsection{Focus on employee values}

Employees are not tools to bring benefits to the enterprise. They have ideas and needs. Therefore, managers hope that employees work hard, they should also meet the basic requirements of employees, instead of blindly making employees work hard. Only when employees' basic needs are fully satisfied, they will not reject too much work. Of course, it is far from enough to meet the needs of the basic level. Leaders should give employees opportunities to show themselves and let them realize that their superiors value for their innovation ability. Leaders should also encourage more employees who have a sense of inferiority and think that they are inferior to others, so as to increase their self-confidence. The influence of values cannot be ignored either in work or in life. Enterprises should guide employees to establish correct work values and improve their innovation ability on the basis of values. The influence of values should not be ignored in work or life. Enterprises should guide employees to establish correct work values and improve their innovation ability on the basis of values.

\section{Conclusion}

This paper takes the employees of agricultural science and technology enterprises as the research object, and finds that transformational leadership has a positive effect on employees' innovative behavior through empirical analysis. However, transactional leadership can be divided into two aspects: contingency reward trading leader has a 
positive impact on employee behavior; exception management transactional leadership has a negative impact on employee innovation behavior. It is a supplement to the theory of the influence of leadership style on employees' innovative behavior. Of course, there are still some defects in this study, for example, data does not cover the whole country, which needs further improvement in the future research.

\section{Acknowledgment}

This research was supported by the Tianjin Philosophy and Social Science Planning Project "Research on Agricultural IoT Investment and Government Subsidy under the Background of Beijing-Tianjin-Hebei Collaborative Development" (TJGL17-021).

\section{References}

1. Amabile T.M., Conti R., Coon H., et al. Assessing the Work Environment for Creativity[J]. Academy of Management Journal, 1996, 39(5):1154-1184.

2. The contribution rate of agricultural science and technology progress in China reached 57.5[EB/OL].

http://www.gov.cn/shuju/2018-

09/21/content 5324151.htm.

3. C.Liu, H.Zhang, S.Wang, C.Ma. Research on the Relationship between leadership style, emotional labor and organizational Citizenship Behavior -Based on the survey data of service-oriented Enterprises [J]. China Soft Science, 2014(03):119134.

4. Doz Y., Kosonen M. The Dynamics of Strategic Agility: Nokia's Rollercoaster Experience[J]. California Management Review, 2008, 50(3):95-118.

5. Burns J.M. Leadership[M]. New York: Harper \& Row, 1978.

6. Bass B.M. Leadership and Performance Expectation[M]. New York: Free Press, 1985

7. Bass B.M., Avolio B.J. Transformational Leadership Development: Manual for the Multifactor Leadership Questionnaire [M]. Consulting Psychologists Press, 1990.

8. Bass B.M..Two decades of research and development in transformational leadership[J]. European Journal of Work \& Organizational Psychology, 1999, 8(1):932 .

9. Amabile T.M., Elizabeth A.S., Giovanni B.M., et al. Leader Behaviors and the Work Environment for Creativity: Perceived Leader Support[J]. The Leadership Quarterly, 2004(15):5-32.

10. Lee J. Effects of Leadership and Leader-member Exchange on Innovativeness[J]. Journal of Managerial Psychology, 2008, 23(6):670-687.

11. Antonakis J. Transformational and Charismatic Leadership $[\mathrm{J}]$. Management Learning, 2012, 45(2):235-236.

12. Jung D.I., Chow C., Wu A. The Role of
Transformational Leadership in Enhancing Organizational innovation: Hypotheses and some Preliminary Findings[J]. Leadership Quarterly, 2003, 14(4):525-544.

13. Shin S J, Zhou J. Transformational Leadership, Conservation, and Creativity: Evidence from Korea[J]. Academy of Management Journal, 2003, 46(6):703-714.

14. Basu R., Green S.G. Leader-member exchange and transformational leadership: An empirical examination of innovative behaviors in leadermember dyads[J]. Journal of Applied Social Psychology, 2010, 27(6):477-499.

15. Jaussi K.S, Dionne S D. Leading for creativity: The Role of Unconventional Leader Behavior[J]. Leadership Quarterly, 2003, 14(4):475-498.

16. Scott S.G., Bruce R. Creating Innovative Behavior among R\&D Professionals: The Moderating Effect of Leadership on the Relationship between Problemsolving Style and Innovation[M]. 1994. 